\title{
IMPORTANCE OF LUBRICANT ANALYSIS
}

\author{
Perić R. Sreten, University of Defence in Belgrade, Military \\ Academy, Department of Military Mechanical Engineering, \\ Belgrade
}

DOI: 10.2298/vojtehg1202156P

FIELD: Mechanical Engineering, Engines and Motor Vehicles

ARTICLE TYPE: Original Scientific Paper

\section{Summary:}

Monitoring the performance of lubricants in practical application has multiple significance for both the consumer and the lubricant manufacturer. The primary significance for the consumer is extended life and timely change of lubricants, which keeps the costs of maintenance down. The lubricant manufacturer gains by creating a partner relationship with the consumer, as well as creating the possibility of gathering information about the performance of his product which will serve as the foundation for its further improvement and development.

If we wish to maintain technical systems so that they have minimum halts and costs caused by halt removal or system failures, we must monitor data indicating equipment condition throughout the system operation. It is especially difficult to obtain data on equipment condition for parts which cannot be observed due to their position. In such cases, the oil analysis enables a continuous equipment condition monitoring and timely response in order to prevent undesirable prolonged halts.

Key words: monitoring, maintenance, Oil Analysis.

\section{Introduction}

The basic role of lubricants i.e. lubrication is to reduce friction and hence prevent the wear of material surfaces the relation of which is conditioned by relative mutual movements. However, it is essential that the lubricant also has other functional properties that will ensure its efficient application. These are, above all, good oxidation and thermal stability, corrosion protection property, compatibility with different materials, low foaming, ability to release air, good detergent-dispersant properties, good deemulsification, and the like.

The use of lubricants inevitably leads to the impairment of its performances. These negative changes are most usually caused by thermal load and/or influence of different kinds of pollution, to which lubricants are exposed during service.

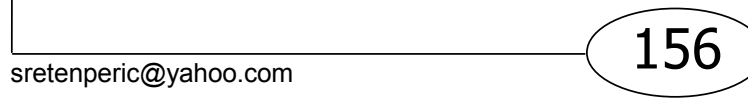


Thermal loads may be generated as a result of high mechanical loads or prolonged exposure to increased temperatures. Different kinds of pollution are also a frequent cause of lubricant degradation. Gaseous combustion products, air, water, glycol, fuel, various process media, wear products, and other pollutants, may be the cause of a serious impairment of the condition of the lubricant, but also of the device itself.

That is why it is necessary to monitor changes in lubricant performances, based on which one may determine a timely change of lubricant, thus prolonging its service life and preventing any major failures or damage to the system.

Knowing analitycal properties of lubricants is the basis for making a decision in development, production and application of lubricants. The lubricant classifications and the approved system specify many performance charracteristics and analytical tests. The analytical tests are classical and instrumental. Instrumental techniques have the advantages such as a small quantity of samples and rapid analyses, but they need a special operator.

Different technical systems require appropriate lubricants to be used at an appropriate position, at appropriate time and in appropriate quantity. Rationalization of lubricant consumption represents a significant task achieveable by on-time oil replacement. This allows for a maximum period of use and, in the same time, appreciable quantity of lubrication. In regard with the primary role of lubricants to reduce the negative effects of tribological processes related to friction, wear and increase of temperature in the tribomehanical systems, all types of maintenance include lubrication as a very important part of the whole procedure.

Being the contact element of the tribomechanical system, lubricant is a carrier of information about the state of the whole system, from the aspect of tribological and other ageing processes. Due to that, an analysis of oils, based on a properly defined program, represents a very effective method for monitoring the state of technical systems, which ensures early warning signals of potential problems that could lead to failure and break down of technical systems.

Using the Oil Analysis programs for engine oils has several benefits: reduction of unscheduled vehicle downtime, improvement of vehicle reliability, help in organizing effectiveness of maintenance schedules, extension of engine life, optimization of oil change intervals and reduction of cost of vehicle maintenance.

\section{Lubricant service life and analysis}

If we wish to maintain technical systems so that they have minimum halts and costs caused by halt removal or system failures, we must monitor data indicating equipment condition throughout the system operation. 
It is especially difficult to obtain data on equipment condition for parts which cannot be observed due to their position. In such cases, the oil analysis enables a continuous equipment condition monitoring and a timely response in order to prevent undesirable prolonged halts.

Numerous test methods are available for monitoring the change of lubricant performances, both conventional laboratory techniques and modern instrumental methods. Determining a lubricant wear degree may be conducted through modeling or experimentally. The wear evaluation, most frequently, is not unequivocal, which is why, in practice, various methods are used combined. For this purpose, new simpler methods are being developed, because it is important to obtain data as soon as possible on the application spot itself, which is very often in the field conditions. A common drawback of these methods is that they have not been standardized yet.

The wear mechanism of a tribological lubrication system consists of the wear of contact surfaces and lubricant consumption. If there is wear of contact surfaces, wear particles are present. Regardless of the availability of numerous methods for diagnosing the physico-chemical changes of lubricants, in order to create a true picture of the condition of lubricants from the user system, it is of importance to satisfy the precondition of the possibility to obtain a representative sample. That is why it is extremely important to obtain the sample in a proper way.

Every sample has to be accompanied by documentation containing all relevant data, such as user name, lubricant name, sample label, date of sampling, date of sample delivery, type of device, lubricant quantity in the system, oil change date, refill data, number of operating hours, operating temperature, reasons for sample supply, and possibly other pieces of information that may be of use for an easier understanding of the actual problem in question and the final interpretation of the obtained analysis results.

These data, along with the obtained analysis results, are the basis for the final lubricant condition interpretation, and hence also the evaluation of its further usability, possible maintenance intervention in order to resolve the problem, if any, and - in case of complaints - their justifiability determination.

Degradation of lubricant properties i.e. wear degree during application or evaluation of the remaining service life is tested by various methods. Determining a lubricant wear degree may be conducted through modelling or experimentally. Wear evaluation most frequently is not unequivocal, which is why, in practice, various methods are used in combinations. For this purpose, new simpler methods are being developed, because it is important to obtain data as soon as possible on the application spot itself, which is very often in the field. A common drawback of these methods is that they have not been standardized yet.

The wear mechanism of a tribological lubrication system consists of the wear of contact surfaces and lubricant consumption. If there is wear of con- 
tact surfaces, wear particles are present. Grease wear (rheological grease wear) or wear of other lubricants is an irreversible change of their properties.

There are many different types of oil analysis tests that are used to evaluate lubricants. The tests must cover three areas: technical system condition, contamination condition, and lubricant condition.

From the technical system condition aspect, the specific focus would be to look for the presence and trending of any wear metals. The second focus would be the lubricant condition. From that aspect, the focus would be to look at the evidence of viscosity change, increase in oxidation, and signs of additive depletion. The third focus would be the contaminant condition. The emphasis should be placed on particle counts, water content, and contaminant metals. Theoretically, oil analyses are divided into three classes. In reality, all three condition-monitoring classes are interrelated and must be considered as a whole. For example, an increase in viscosity could be an indicator that a lubricant is oxidizing. But oxidation could be an incorrect conclusion, if there is no indication of an increasing oxidation trend either by acid number (AN) values or the Fourier Transform-Infrared (FTIR) analysis.

By monitoring its condition, actions can be implemented to refresh or replace the lubricant before serious technical system damage begins. If damage is noticed in the course of operation, due to contaminant, or lubricant problems, the technical system condition can be monitored and the machine may be shut down immediately to minimize damage.

There are two types of alarming methodologies that are employed in the oil analysis: absolute and statistical alarms. The effective oil analysis relies on the combination of both types of alarms. The warning limit is the absolute alarm. Statistical trending, taking into account the variability based on the sampling, contamination, etc. will develop the standard deviations. Departure from this normal variability signals that genuine problems are occurring. This is the earliest possible time to take action and resolve problems. Failing this, as the trend approaches its warning limit, an action such as changing or cleaning the oil, or an inspection of the unit is required.

The test used could be iron content, viscosity or other parameters. The normal result variability range takes into account minor variations caused by analytical accuracy, sample homogeneity, etc. As the trend approaches the warning limit, some action must be taken, either cleaning the oil or inspecting the equipment. Establishing statistical alarms, which provide the earliest possible warning without false alarms, is a difficult task. The factors such as adding or changing oil, filter changes, sampling technique can distort the results.

The following tests are the most frequently used ones in condition monitoring:

- Spectrometric Analysis,

- Analytical Ferrography,

- Rotrode Filter Spectroscopy (RFS), 
- Infrared Analysis (FTIR),

- Viscosity,

- Total acid number (TAN),

- Total Base Number (TBN)

- Water and Particle Count.

\section{Impact of lubricants on the environment during application}

Waste oils fall into the category of hazardous technological waste, which means that their management prevents possible environmental pollution generated by their improper disposal i.e. possible leakage. Out of total global oil processing, $1 \%$ is used for lubricant production.

All types of lubricants are considered as harmful contaminants to the environment. Waste lubricants are classified as dangerous, toxic and cancerogenic waste materials and soil, water and air contaminants. Toxicity and cancerogenity are, primarily, based on the products of oxidation and thermal degradation of lubricants. Oxidation processes of lubricants are continuous, not only during exploitation, but also during storage. These processes produce acid products, resins and asphaltenes. Under the influence of high temperatures and along with the catalytic effect of hot metal surfaces of pistons and cylinders (motor oil), harmful products containing polycyclic aromatics (PCA) of various cancerogenic potential are generated.

In some waste oils the presence of polychlorinated biphenyls (PCB) has been identified with high toxicity and cancerogenic impact which destroys the immune system. Besides, waste oils contain nitrogen and sulfur oxides, as products of fuel oxidation with which they are in contact.

Uncontrolled spilling of waste oils is a serious threat to the environment because it destroys natural balance. Oil concentration in water of merely 1-2 mg per litre already makes the water unfit for drinking and health hazardous. Another aspect of the danger appears when waste oils of first and second category are incinerated. Since waste oils contain additives based on compounds of sulphur, nitrogen, phosphorus and heavy metals, both ash and the incineration gases are most hazardous for human health.

When it comes to occupational diseases associated with handling lubricants, the most frequent ones are dermatitis and respiratory diseases. Dermatitis or skin disease appears in the following three forms: irritation, chronic dermatosis and alergy. It is a reaction of skin as an organism barrier in contact with the lubricant. Respiratory diseases (asthma, bronchitis) are the result of the activity of either oil mist or aerosol, generated in the plants due to increased temperatures, high speeds, and the like. Between the lubricant (mist, aerosol) and respiratory system cells, a chemical reaction occurs. 
This is the reason for an increased development of environmentally adapted lubricants, EAL. Such lubricants reduce the costs of management, water protection, maintenance, interphase cleaning, water reconditioning after splitting, etc. EALs are also usually non-toxic, while they also posses better skin compatibility. The properties of environmentally adapted lubricants are:

- fast biodegradability,

- low water pollution degree,

- poor water solubility,

- unharmfulness or low toxicity,

- heavy metals-free additives,

- non-incineration/high flash point, water fluids,

- low volatility - high flash point,

- application of natural feeds - ester oils, rapeseed, soya oil, animal oils.

Environmentally adapted lubricants are applied on spots where they are entirely lost into the environment, the so-called total-loss lubrication. These are mobile hydraulic systems, lubricants for railroad switches, saws, concrete mould oils, etc. They are also applied in industry, hydraulics and industrial gear oils. In formulations of EAL lubricants, the following additives should be avoided: compounds based on lead, chlorine, barium and zinc (such as ZDDP). Instead of them, phosphatic acid esters and alkylene carbamates are applied as well as compounds based on "green" bismuth, and other non-harmful compounds. As base oils, one may use synthetic esters, polyglycols, and some other synthetic base components.

Most desirable is the application of natural oils which may provide good properties for a lubricant as both additives and base oils. During application, we have observed important changes in the activity of synthetic and natural components with regard to formulations with mineral oil. That is why tests have been increased, evaluating primarily the oxidation and temperature stability and the compatibility of the additive and the base oil component. Furtherly evaluated is their polarity, surface activity, chemical reactivity, the ability to create a lubricating film, wear protection, load carrying capacity, heat transfer, dependence of viscosity on temperature, etc.

\section{The tribomechanical systems}

The central component of the tribomechanical system is the lubricant, the most significant function of which is the lowering of friction and wear appearing in the contact of two surfaces in relative motion. As subsystems, tribomechanical systems are integrated everywhere into technical systems. Apart from more significant applications in internal combustion engines, transmission, and hydraulic systems, there is also a number of further applications. Due to the poor execution of a tribomechanical system or its inadequate application, if it is not fit for the given system, commercial losses may occur, mea- 
sured in billions of Euros annually. This is why the significance of tribosystems is not only technical, but also economic and environmental. The concept of the future successful development endeavours to associate economy and ecology into a complex and non-contradictory system.

By recognizing the function of the tribomechanical system and through a rich development of materials, equipment and methods, it seemed that all the problems associated with lubrication had been resolved. However, lubrication engineering still remains active. The goal is to develop tribomechanical systems that will be less environmentally harmful while having high technical performances. Development of technical products is dependent on a number of both general and specific requests.

General requests are: (environmental) com-patibility, high technical performances, application efficiency of lubricants, structure and materials, and lubricant price i.e. economical character. Specific requirements are: reduced need for fluids/lubricants - compensation by materials, application of natural or chemically modified natural stocks, production of lubricants at reduced cost, use of databases or numerical methods, saving of energy and natural resources.

The lubricant economical character does not entail only its purchase price, but is also a result of evaluating a series of properties. These are compatibility (multifunctional lubricants), ageing and temperature stability, oil change interval, possibility of recycling, management costs, maintenance measures, investments into machinery, and also estimation of operating and storage expenses, emission control measures, health protection and occupational safety measures, simpler procedure for obtaining approvals for application, and reduction of costs for managing oil spills and their cleanup.

Real systems are complex tribomechanical systems. Conditions of the elements of tribomechanical systems are very complex and determined largely by adequate characteristics of lubricants. The complexity of conditions is determined by:

- the temperature of elements in contact and the temperature of lubricant,

- outer load (specific pressure in the contact zone),

- dynamic character of making contact and power and motion transmission.

A vehicle as a technical means is a set of complex tribomechanical systems composed of a range of subsystems that are also complex tribomechanical systems. They are composed of elements participating in power transmission, (moment of force from the engine, over transmissions (power transmitter, differential and other systems), to executive organs of a vehicle.

If the engine assemblies are considered from the aspect of tribomechanical systems (e.g. assemblies piston-piston ring-cylinder, cam-valve lifter, bearing-journal bearing) defined by tribological processes, it can be shown that the determination of the content of wear products, content of 
contaminants, state of lubricants and lubrication conditions have a significant influence on the implementation of maintenance of these systems.

We should emphasize the importance of monitoring oil for lubrication of tribomechanical engine assemblies, which provides that in the early stages of the functioning of the system we can identify potential causes and phenomena that lead to damage and failure. Prognostication and detection of potential and/or current damage and failures in the system, as well as checking the functionality of oil and determination of usage life are the main factors of the implementation of oil monitoring.

\section{Diagnosis of tribomechanical vehicle assemblies}

Vehicles are very complex technical system which endure intense and different exploitation conditions. New vehicles are equipped as moving laboratories which do not lack data (in number and kind). Vehicles have gained OBD systems (On Board Diagnostics) because of ecological reasons. When some other information isadded, there are conditions for forming FSS (Flexible Service Systems) [1].

Diagnostics of tribomechanical systems can provide validation, working capacity and the functionality of systems, and it can point out the place, form and cause of failures. It is possible to diagnose the system through the detection of symptoms in order to determine the value of the characteristic parameters and their comparison with the limit values. Diagnostics of tribomechanical systems in motor vehicles is a part of the overall process of managing maintenance. It provides an opportunity for the user to predict the damage and/or failure, and thus prevent delay in the work and extend usage life of motor vehicles.

The essence of diagnosis is based on the prognostication (recognition) of damage and/or failure through characteristic diagnostic parameters. This allows prevention of the occurrence of delays, and increases reliability, economy, and usage life. Confirming the basic causes of failures and their elimination, control of certain phenomena, is defining proactive maintenance as a new method that reduces maintenance costs and prolongs the life of assets.

As a part of the common proactive strategy of the hydraulic systems maintenance, the concept of on-line monitoring has been introduced recently in practice, It is a combination of measurement procedures by which a sample of fluid to be analysed is taken directly from the system and the results of the measurements are shown continuously.

Modern trends of diagnosis in recent years go to the affirmation of oil monitoring, which has resulted in growth of interest of producers and users of oil. The reasons lie primarily in increasing the reliability, effectiveness, economy, and recently increasingly present protection of the environment. 
By analyzing a great number of failures of complex tribomechanical systems, we can conclude that there have been certain changes both in systems that failed and in lubricants. Namely, a failure of a tribomechanical system can appear due to changes in lubricant characteristics, or changes in lubricant characteristics can appear due to a failure of other elements of a tribomechanical system.

In most cases, a change in the functionality of a complex tribomechanical system is a change of lubricant characteristics, so a change of lubricant tribological characteristics can be accepted as a parameter for the evaluation of the tribomechanical system condition.

Lubricant characteristics can be divided in two groups:

a) physico-chemical characteristics:

- viscosity (dynamic-absolute-viscosity; kinematic viscosity),

- density,

- flash point,

- cloud point,

- pour point,

- volatillity,

- emulsibillity,

- deemulsibillity,

- foaming,

- air release,

- chemical composition,

- total acid number (TAN),

- oxidation stabillity,

- thermal stabillity,

- corrodibillity,

- corrosin protection capabillity,

- water content.

b) physico-chemical characteristics:

- frictional force,

- frictional coefficient,

- wear intensity,

- contact temperature,

- intensity of increasing of wear products.

\section{Engine oils}

The primary role of engine oil is lubrication of moving engine parts and reducing friction and wear of metal surfaces, which provides good engine performance and its long life. In order to provide a defined quality of engine oils during production and for final products to meet the product specifications, we need to know the physico-chemical characteristics of engine oils. 
Certain physico-chemical characteristics significant for the quality of engine oils are achieved by adding additives to base oils. The most frequent additives are for:

- Improving viscosity index-improvers

- Reducing pour point-depressants

- Maintaining engine cleanness-detergents and dispersants

- Preventing oxidation-antioxidants

- Preventing corrosion-corrosion inhibitors

The most important engine oils characteristic is the viscosity defined as a measure of inner friction which works as a resistance to the change of molecule positions in fluid flows when they are under the impact of shear force, or in other words, it is the resistance of fluid particles to shear. When fluids flow, there are friction forces between their particles and also between fluid particles and the adjoining surface, caused by the resistance of fluid to particle shear and also of surface roughness. The viscosity is a changeable category and it depends on the change of temperature and pressure. A higher temperature reduces the viscosity and makes a fluid thinner.

The viscosity index is an empirical number which shows how the viscosity of some oils changes by increasing or reducing the temperature. A high viscosity index shows relatively small tendency of viscosity to change upon influence of certain temperature, as opposed to a low viscosity index which shows a greater viscosity change with temperature. The calculation is based on viscosity values determined by the ASTM D 445 method at 40 and $100^{\circ} \mathrm{C}$.

Viscosity index improvers impact the oil behaviour as far as flow characteristics are concerned. The sensitivity of viscosity index improvers to mechanical stresses increases with the increase of polymer additives molecular weight. High shear stress causes the irreversible molecular degradation of polymers and reduces their molecular weight. This reducing of an average molecular weight results in reducing the viscosity and viscosity index [2].

Colloidal systems are created by the dissolution of polymeric viscosity index improvers in mineral oil. They have different physical properties depending on the nature and length of molecules and also on the type of a solvent. These properties are defined by their shape, conformation of dissolved molecules and their variation in temperature.

Additives for the viscosity index improvement influence the following characteristics of multigrade engine oils [3]:

- at low temperatures they maintain the oil sufficiently liquid, which means when starting the engine with low internal friction, just the minimal engine power is used and it provides a safe engine starting,

- at high temperatures they give the oil higher viscosity which provides a necessary oil film thickness and small oil consumption.

Multigrade engine oils, among numerous additives, always contain viscosity index improvers as well. These additives are special types of polymers, 
which in small concentration significantly improve engine oils rheological properties, especially viscosity and viscosity index. However, during engine oils utilization, degradation of viscosity index improvers, i.e. break down of polymeric molecules, occurs. It results in the reduction of their molecular weight that leads to viscosity loss and oil film thickness decrease, which causes undesirable phenomena of friction and wear. The shear stability of the viscosity index improvers, i.e. the polymer resistance to mechanical degradation under shear stress, is determined by measuring the viscosity loss after repeated oil passing through the injector nozzle. The engine oil specifications define the minimal oil viscosity grade after the shear.

By introducing the new ACEA and API specifications, the requirements for the shear stability of engine oils have been changed and now they are accepted by engine and vehicle manufacturers. In order to achieve a better correlation with engine oil application results, it is defined that the shear stability should be determined by a standardized apparatus extending current testing of 30 to 90 cycles of oil passing through the nozzle.

\section{Engine oil investigation during exploitation}

The physico-chemical characteristics of oil in accordance with standard methods are examined, shown in table 1 . The analysis was done on the fresh (new) oils and oils used in motor assembles of vehicles. Testing of used samples was carried out in accordance with common criteria defined by the quality of used oil.

Allowable values of deviation limits of individual characteristics of the oil are conditioned by the type of oil, working conditions and internal recommendations of the manufacturer of lubricants and users. Limited value characteristics of oils that condition the change of oil charging from engine are given in Table 2. They represent the criteria for the change of oil charge. A deviation of only one source changes the characteristics of oil charge, no matter what characteristic is about.

Implemented tests and methods for examining the physico-chemical characteristics of oil [4]

Primenjeni testovi i metode za ispitivanje fizičko-hemijskih karakteristika [4]

Tabela 1

\begin{tabular}{|l|l|}
\hline Characteristic & Method \\
\hline Density, gr/cm & JUS B.H8.015 \\
\hline Kinematic viscosity, $\mathrm{mm}^{2} / \mathrm{s}$ & JUS B.H8.022 \\
\hline Viscosity Index & JUS B.H8.024 \\
\hline Flash Point ( $\left.{ }^{\circ} \mathrm{C}\right)$ & ISO 2592, ASTM D 92 \\
\hline Pour Point $\left({ }^{\circ} \mathrm{C}\right)$ & ISO 3016 \\
\hline Foaming, $\mathrm{ml} / \mathrm{ml}: 24^{\circ} \mathrm{C} ; 94^{\circ} \mathrm{C} ; 24^{\circ} \mathrm{C}$ & ASTM D892 \\
\hline Water Content, mas. $\%$ & ASTM D 95 \\
\hline Total Base Number (TBN), $\mathrm{mgKOH} / \mathrm{g}$ & ASTM D 2896 \\
\hline Insoluble substances in pentane, $\%$ & ASTM D 893 \\
\hline Insoluble substances in benzene, $\%$ & ASTM D 4055 \\
\hline Fe Content, $\%$ & ASS \\
\hline
\end{tabular}


Table 2

Allowed values deviation of physico-chemical characteristics of new and used oil [4]

Tabela 2

Dozvoljene vrednosti odstupanja fizičko-hemijskih karakteristika novog i korišćenog ulja [4]

\begin{tabular}{|l|c|}
\hline $\begin{array}{l}\text { Physico-chemical characteristics oil and } \\
\text { products wear }\end{array}$ & Maximum allowed variation \\
\cline { 2 - 2 } & Motor oil \\
\hline Viscosity at $40^{\circ} \mathrm{C}$ and $100^{\circ} \mathrm{C}, \mathrm{mm}^{2} / \mathrm{s}$ & $20 \%$ \\
\hline Viscosity Index, $\%$ & $\pm 5 \%$ \\
\hline Total Base Number $(\mathrm{TBN}), \mathrm{mg} \mathrm{KOH} / \mathrm{gr}$ & The fall to $50 \%$ \\
\hline Flash Point, ${ }^{\circ} \mathrm{C}$ & $20 \%$ \\
\hline Water Content, $\%$ & $0.2 \%$ \\
\hline Indissoluble substances in pentane, $\%$ & 3.5 \\
\hline Indissoluble substances in benzene, $\%$ & 2.5 \\
\hline Products wear - Content Fe, $\mathrm{ppm}\left({ }^{\circ} \mathrm{g} / \mathrm{gr}\right)$ & $100 \mathrm{ppm}$ \\
\hline Products wear - Content Cu, ppm $\left({ }^{\circ} \mathrm{g} / \mathrm{gr}\right)$ & $50 \mathrm{ppm}$ \\
\hline
\end{tabular}

The origin of several elements in the used engine oil (Table 3) may be from additives $(\mathrm{Zn}, \mathrm{Ca}, \mathrm{Ba}$ and $\mathrm{Mg})$, the wear products $(\mathrm{Fe}, \mathrm{Pb}, \mathrm{Cu}$, $\mathrm{Cr}, \mathrm{Al}, \mathrm{Mn}, \mathrm{Ag}$ and $\mathrm{Sn}$ ) and contaminants originating from fuel, air and liquid cooling ( $\mathrm{Na}, \mathrm{B}, \mathrm{Si}$ and $\mathrm{Ca}$ ).

The origin of certain wear elements in the engine oil [4]

Poreklo pojedinih elemenata u motornom ulju [4]

\begin{tabular}{|c|l|}
\hline Elements & Wear Metal Source \\
\hline $\mathrm{Fe}$ & $\begin{array}{l}\text { cylinder liners, piston ring, journal bearing, valve lifter, camshaft, } \\
\text { crankshaft }\end{array}$ \\
\hline $\mathrm{Al}$ & piston, Al-Sn bearings, turbocharger \\
\hline $\mathrm{Ag}$ & silvered parts, bearings, journals \\
\hline $\mathrm{Cr}$ & $\begin{array}{l}\text { hard chrome plated parts, pistons, cylinders, valve lifter, exhaust valve, } \\
\text { connecting rods }\end{array}$ \\
\hline $\mathrm{Cu}$ & $\begin{array}{l}\text { Cu-Pb bearings, bushings, oil coolers, camshaft, valve train (valves with } \\
\text { system for opening and closing), fuel injector, regulator }\end{array}$ \\
\hline $\mathrm{Pb}$ & Cu-Pb bearings, gasoline, additives \\
\hline $\mathrm{Sn}$ & bronzed parts, bearings, pistons \\
\hline $\mathrm{B}$ & antifreeze \\
\hline $\mathrm{Na}$ & antifreeze \\
\hline $\mathrm{Ca}$ & from atmosphere \\
\hline $\mathrm{Sn}, \mathrm{Mg}, \mathrm{Mo}$ & particles from atmosphere \\
\hline
\end{tabular}

The research was carried out in a vehicle with an embedded Mercedes-Benz EURO 2 engine, type OM 906 HLA. This is a four-stroked engine with six cylinders arranged in line, turbo diesel, liquid refrigeration and with a combined lubrication, which meets Euro 2 emission standards related to exhaust gases. The technical data of the engine are given in table 4.

The results for the used oil samples are given in Table 5 . 
Technical data for Mercedes-Benz engine, type OM 906 HLA [4]

Tehnički podaci motora Mercedes-Benz, tipa OM 906 HLA [4]

\begin{tabular}{|l|l|}
\hline \multicolumn{2}{|c|}{ Engine Mercedes-Benz, type OM 906HLA } \\
\hline Engine type & $\begin{array}{l}\text { four-stroked, turbo } \\
\text { diesel (EURO 2) }\end{array}$ \\
\hline Number and spacing of cylinders & 6, linear \\
\hline Engine capacity, litres & 8.5 \\
\hline Compression ratio & $23: 1$ \\
\hline Nominal output, in 2100 $\mathrm{min}^{-1}, \mathrm{KW}$ & 180 \\
\hline Maximum torque, in $1100 \mathrm{~min}^{-1}, \mathrm{Nm}$ & 1050 \\
\hline
\end{tabular}

The results of testing samples of used oil from the examined vehicle engine [4]

Tabela 5

Rezultati ispitivanja korišćenih uzoraka ulja iz motora razmatranog $\mathrm{m} / \mathrm{v}$ [4]

\begin{tabular}{|l|c|c|c|c|c|}
\hline \multirow{2}{*}{ Characteristic } & \multicolumn{5}{|c|}{ Milleage (in kilometers) } \\
\cline { 2 - 6 } & 0 sample & 5000 & 10000 & 15000 & 20000 \\
\hline $\begin{array}{c}\text { Viscosity } \\
40^{\circ} \mathrm{C}, \mathrm{mm}^{2} / \mathrm{s}\end{array}$ & 107.28 & 101.12 & 97.75 & 97.42 & 96.17 \\
\hline $\begin{array}{c}\text { Viscosity } \\
100^{\circ} \mathrm{C}, \mathrm{mm}^{2} / \mathrm{s}\end{array}$ & 14.45 & 13.81 & 13.61 & 13.60 & 13.39 \\
\hline Viscosity index & 138.0 & 138.0 & 140.0 & 140.0 & 139.0 \\
\hline Flash point, ${ }^{\circ} \mathrm{C}$ & 202 & 200 & 192 & 188 & 186 \\
\hline $\begin{array}{l}\text { TBN, } \\
\mathrm{mg} \mathrm{KOH} / \mathrm{g}\end{array}$ & 8.50 & 7.20 & 6.09 & 5.85 & 4.24 \\
\hline $\begin{array}{l}\text { Content water, } \\
\%\end{array}$ & 0 & 0 & 0 & 0 & 0 \\
\hline $\begin{array}{l}\text { Insoluble } \\
\text { substances in } \\
\text { pentane, [\%] }\end{array}$ & 0.07 & 0.07 & 0.07 & 0.08 & 0.29 \\
\hline $\begin{array}{l}\text { Insoluble } \\
\text { substances in } \\
\text { benzene, \% }\end{array}$ & 0.13 & 0.15 & 0.14 & 0.17 & 0.35 \\
\hline $\begin{array}{l}\text { Content Fe, } \\
\text { ppm }\end{array}$ & 5.8 & 23.0 & 25.2 & 29.6 & 92.8 \\
\hline
\end{tabular}

The engine used FENIX SUPERIOR engine oil, quality API SF-CD, gradation SAE 15W-40. The testing was performed in the conditions of urban driving. The task was to check the interval to replace engine oil after $20.000 \mathrm{~km}$. It was found that the changes characteristic for engine oil were expected and within the allowable limits.

The research was conducted through a periodic sampling of the oil from the vehicle engine listed above. Apart from fresh oil (,,zero" sample), samples were taken after $5.000 \mathrm{~km}, 10.000 \mathrm{~km}, 15.000 \mathrm{~km}$ and $20.000 \mathrm{~km}$. After $20.000 \mathrm{~km}$ the oil was changed. 
During the oil sampling, the choice of samples was made carefully according to the actual oil usage, which enabled each sample to be a representative one. Each sample was taken from the living zone, i.e. zone closer to the elements in contact. In that way we avoided the sampling of oil from the bottom of the motor housing (outlet for discharge), as is at the bottom of the largest concentration of contaminants. This is achieved simply by modifying the outlet for oil extending toward the active zone of oil within the housing with the appropriate length of tubule [4], [5], and [6].

Also, a special attention is paid to the preservation of samples from contamination, both in the phase of identifying the sample and in the phase of manipulation, which is fully met by applying the prescribed procedures. In accordance with the time provided, a very high level of purity of all elements in the chain of systems for sampling is achieved, as well as the separation of samples without undermaining the integrity of data about the state of vehicle components from which sampling was done $[7,8]$.

The viscosity index is an empirical number which shows how the viscosity of some oils changes by increasing or reducing the temperature. A high viscosity index shows a relatively small tendency of viscosity to change upon influence of certain temperature, as opposed to a low viscosity index which shows a greater viscosity change with temperature. During exploitation, it is desirable that the viscosity changes as little as possible with the change of temperature. If, during work, temperature modes are changeable and cause major changes of viscosity, that may cause disruptions in the functioning of the system, which is a manifestation of increased friction, wear and damage.

The change of the engine oil Viscosity Index is shown in the Fig. 1. The decrease in the Viscosity Index oil is evident, but it does not exceed the limit of $5 \%$ (Table 2).

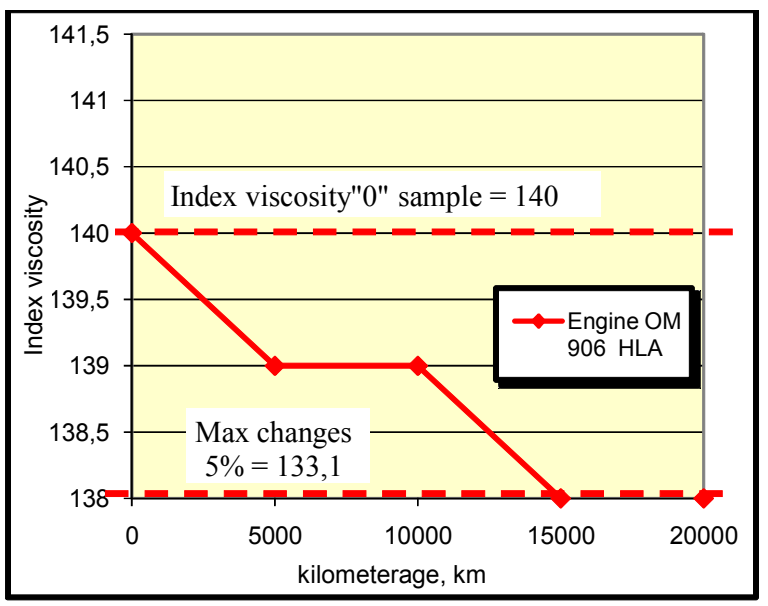

Figure 1 - The change of the viscosity index Slika 1 - Promena indeksa viskoznosti 
The reasons for the increase of lubricant viscosity are as follows: oxidation of lubricants, cavitation due to lubricant foaming, dissolution of lubricants with water, pouring and charging of a system with lubricant of higher viscosity than recommended and lubricant contamination with solid particles and products of wear.

The reasons for the reduction of lubricant viscosity are: lubricant contamination of fuel (for motor oil), shearing additive for viscosity improvement, drop point of flash, grinding molecules, lubricant contamination without solubility with water, pouring and charging of a system with lubricant of lower viscosity than recommended, and the impact of liquid cooling. In addition, causes may be high temperature, load, uncontrolled long interval of usage, insufficient amount of oil in the oil system, inefficient cooling systems, etc.

As expected, kinematic viscosity usually decreases in time due to fuel penetration, or - in well-maintained engines, there occurs a slight increase as a result of the increase of oil insolubles, without fuel penetration.

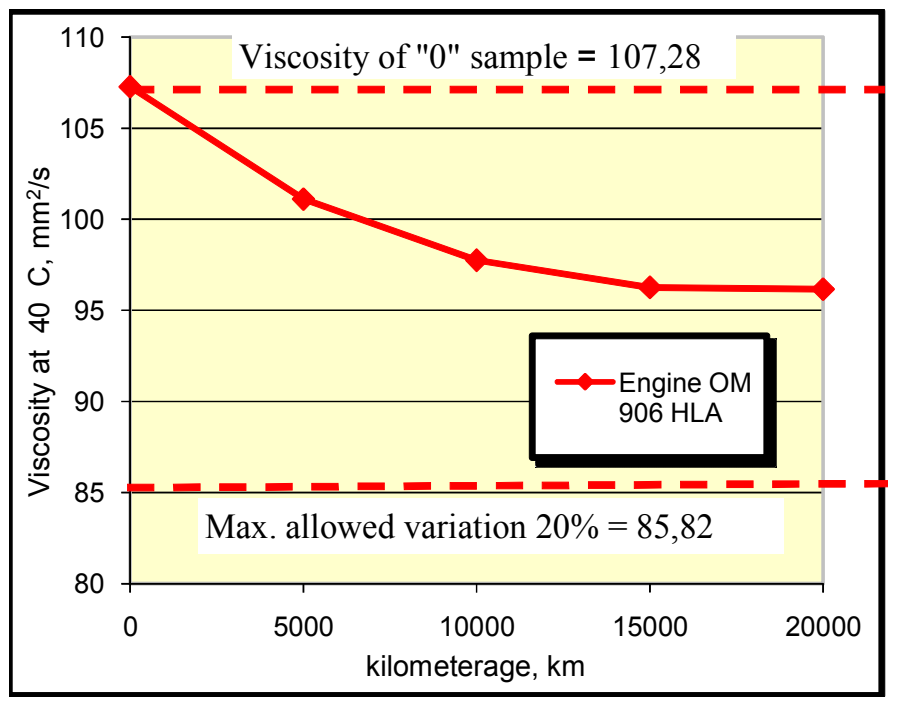

Figure 2 - The change of viscosity at $40^{\circ} \mathrm{C}$ Slika 2 - Promena viskoznosti na $40^{\circ} \mathrm{C}$

Fig. 2 shows the changes of viscosity at $40^{\circ} \mathrm{C}$ of the engine oil during exploitation. There is a fall in the engine oil viscosity after the first $5.000 \mathrm{~km}$ and after this period, the viscosity remains approximately constant until the end of the interval for oil change. The fall in viscosity for the entire period of exploitation of oil is $10.3 \%$. This is far below the allowed limit of $20 \%$ (Table 2).

Fig. 3 shows the changes of engine oil viscosity at $100^{\circ} \mathrm{C}$. The fall in the viscosity for the entire period of exploitation of oil is $7.3 \%$, which is also below the allowed limit of $20 \%$ (Table 2 ). 


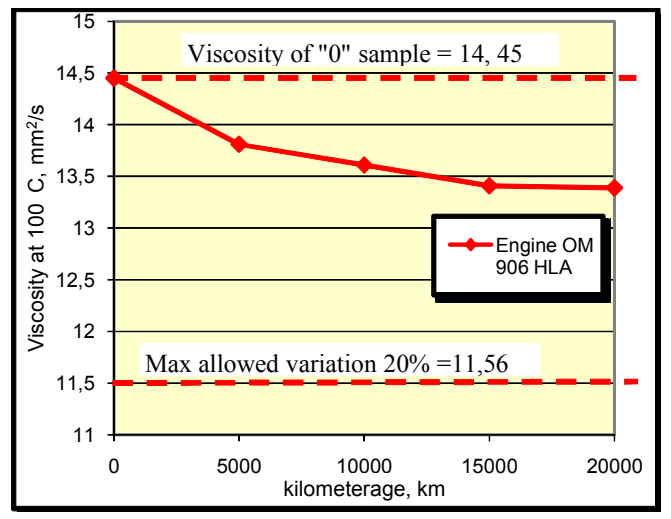

Figure 3 - The change of viscosity at $100^{\circ} \mathrm{C}$

Slika 3 - Promena viskoznosti na $100^{\circ} \mathrm{C}$

The total base number (TBN) is a neutralization number intended for measuring all basic (alkaline) materials in the lube (acid-neutralizing components in the lubricant additive package). The TBN is generally accepted as an indicator of the ability of oil to neutralize harmful acidic byproducts of engine combustion. The TBN is highest when oil is new and decreases with its use. A low TBN normally indicates that the oil has reached the end of its useful life. The TBN is a measure of the lubricant alkaline reserve, and mostly applies to motor lubricants. If a lube contains no alkaline additives, there is little use to determine the TBN, as there will likely be none. Combustion acids, e.g. sulfuric acid, attack the TBN.

Fig. 4 shows the changes of the total base number (TBN). Up to $20.000 \mathrm{~km}$, the TBN value exceeds the allowed limit. The fall of the TBN for the entire period of exploitation of oil is $19.61 \%$, which is above the allowed limit of $50 \%$ (Table 2).

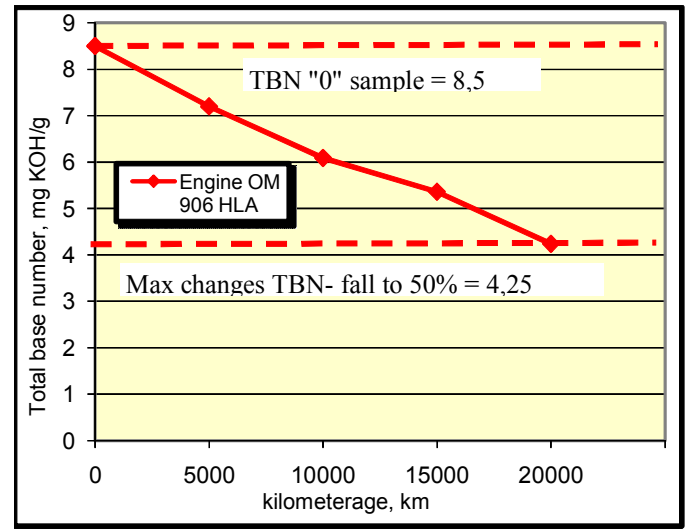

Figure 4 - The change of the TBN

Slika 4 - Promena TBN 


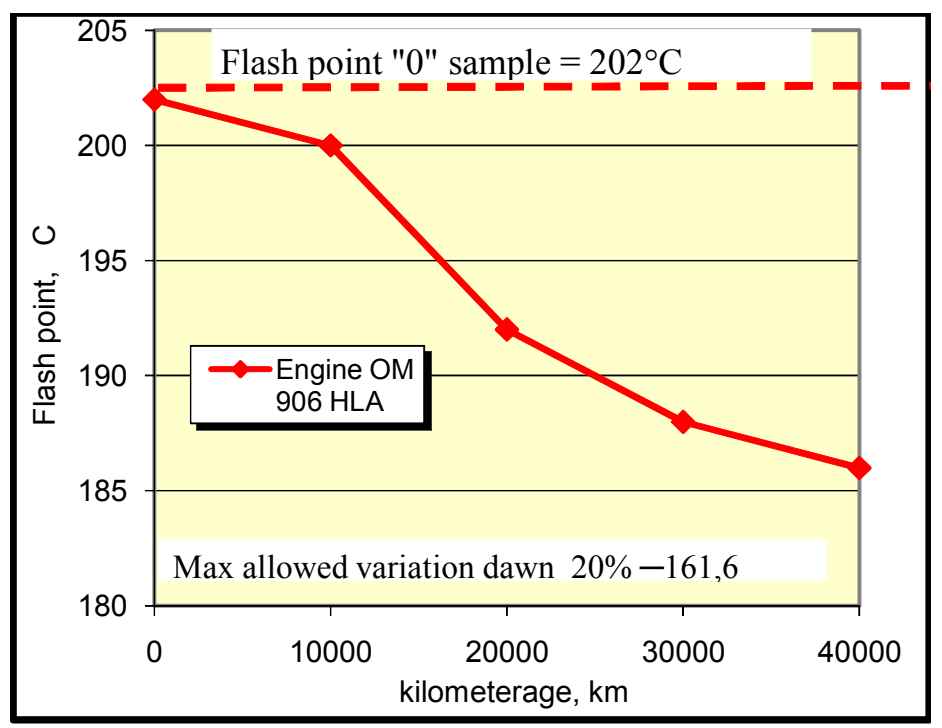

Figure 5 - The change of the Flash point Slika 5 - Promena tačke paljenja

The flash point represents data that shows which temperature leads to open fire ignition by the steam created by oil heating. In the engine oil analysis, the flash point determines the presence of fuel oil, which is a consequence of poor motor (bad work of injectors). The reduction of the flash point is due to the penetration of fuel.

Fig. 5 shows the change of the flash point for engine oil. The decrease in the flash point is noticeable, and by the end of exploitation testing, it does not exceed the allowed limits $(20 \%$, Table 2$)$. The drop of the flash point is $8 \%$. This indicates that there was no significant penetration of fuel in the engine lubrication system for the above mentioned vehicle.

Insoluble residues after treatment in pentane are oxidant products and mechanical impurities, while insoluble residues after treatment in benzene are insoluble materials such as coke, scale, dust, soot, particles originated from wear of the contact area of tribomechanical systems and other mechanical impurities.

A graphical display of the changes in the value of insoluble substances in pentane and benzene is given in Figs. 6 and 7 . The content of insoluble substances in the oil is negligible compared to the allowed deviation values (maximum insoluble in pentane $0.29 \%$, and it is allowed up to $3.5 \%$, maximum insoluble in benzene $0.37 \%$, and it is allowed up to $2.5 \%$ ). 


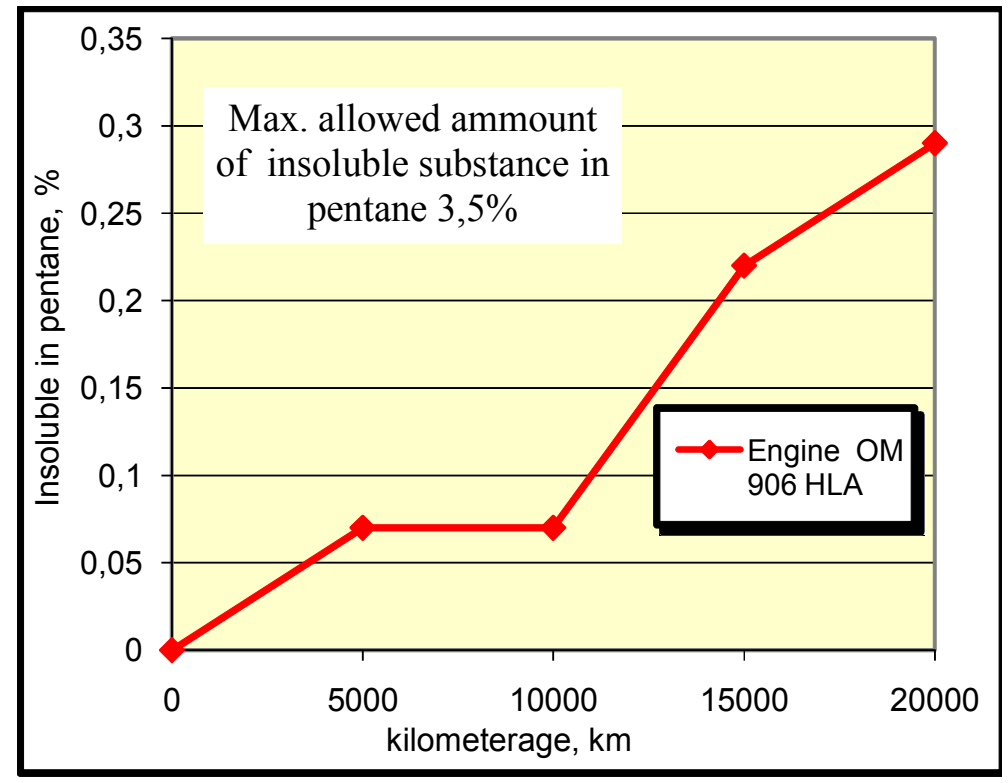

Figure 6 - The change of the amount of insoluble substances in pentane Slika 6 - Promena količine nerastvornih materija u pentanu

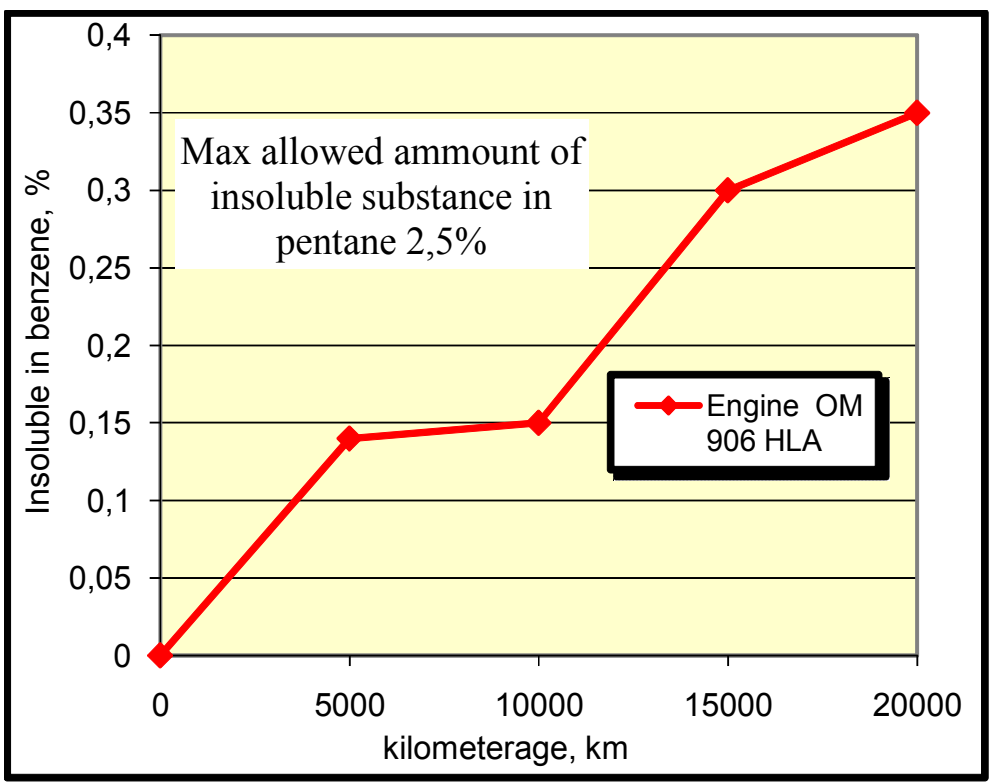

Figure 7 - The change of the amount of insoluble substances in benzene Slika 7 - Promena količine nerastvornih materija u benzenu 


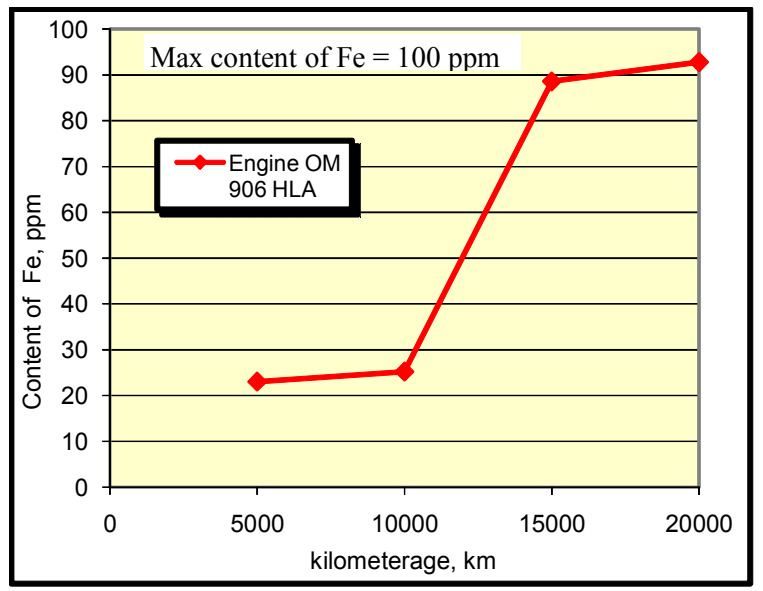

Figure 8 - The change of the Fe content in motor oil Slika 8 - Promena sadržaja Fe u motornom ulju

In order to view the degree of wear of the elements in the engine tribomechanical system, the atomic absorption spectrophotometry (AAS) is applied for oil sampled from the examined engines. This method is determined by the type and concentration of metal $(\mathrm{Fe})$ in the oil charge.

Atomic absorption spectrophotometry is a very sensitive, simple, fast and reproductive method, used for the detection of most elements. It is based on the measurement of light absorption by atoms in the non-excited state. The reduction of missed light intensity increases proportionally with the increase of the number of atoms in the non-excited state.

Absorption is determined by measuring changes in intensity before and after the leakage of light through the atomic gas and it is proportional to the concentration of the measured element. If the concentrations of elements are small, light absorption is linearly dependent on the concentration. A metal such as iron (Fe) was selected for identification because it is a typical element contained in the examined engine. On the basis of changes in its concentration in the oil charge, its origin from the engine elements can be determined as well as the degree of wear.

To the end of the exploitation testing, the iron content (Fig. 8), as a product of wear in the oil charge, has a growing trend and in the last sampling, after $20.000 \mathrm{~km}$, it has $92.8 \mathrm{ppm}(92.8 \%)$ of the maximum allowed value.

\section{Conclusion} be drawn:

On the basis of all mentioned above, the following conclusions can

- FENIX SUPERIOR engine oil, API SF-CD, gradation SAE 15W-40, is analyzed during the exploitation, and it achieves its primary function 
and meets the prescribed replacement interval of $20.000 \mathrm{~km}$ for EURO 2 engines, which is found the characteristic analysis of physico-chemical properties of oil products and wear (Fe) during exploitation;

- the drop of viscosity is evident during the first $5.000 \mathrm{~km}$, and after this period viscosity remains approximately constant until the end of the interval of changes of the oil charge. The maximum drop of viscosity during the exploitation of oil is significantly below the allowed limit of $20 \%$;

- after $20.000 \mathrm{~km}$ the TBN value exceeds the allowable limit for oil samples from engines;

- the content of insoluble substances in the oil is negligible in comparison to the limit value, because there is no significant presence of oxidation products and mechanical impurities, insoluble substances such as coke, scale, dust, soot, particles originated from wear of the contact area of the engine tribomechanical system and other mechanical impurities;

- small decrease of flash point values shows that there is no significant penetration of fuel into the system for lubrication;

- content of iron is below the allowable limits.

The need for more effective maintenance and possibility of continuous exploitation of equipment has developed numerous strategies and methods for machinery maintenance. The maintenance strategy by condition, requiring continuous equipment monitoring, has initiated the development and use of the oil analysis.

\section{References}

[1] Pešić, R., Veinović, S., Pavlović, R., Dijagnostika složenih tehničkih sistema na primeru motornih vozila, Traktori i pogonske mašine, Vol. 6., No. 3, pp. 79-87, 2001.

[2] Mortier, R. M., Orszulik S. T., Chemistry and Technology of Lubricants, Blackie Academic \& Professional, London, 1997.

[3] Maziva i podmazivanje, JUGOMA, Zagreb, 1986.

[4] Perić, S., Doprinos razvoju metoda dijagnostike stanja sa aspekta fizičko hemijskih i triboloških karakteristika ulja kod motornih vozila, doktorska disertacija, Beograd, 2009.

[5] Perić, S., Nedić, B., Monitoring oil for lubrication of tribomechanical engine assemblies, Journal of the Balkan tribological association, Volume 16, pages 242-257, University of Sofia, Bulgaria, 2010.

[6] Perić, S., Nedić, B., Vuruna, M., Monitoring Physical and Chemical characteristics Oil for Lubrication,, Journal Tribology in industry, Volume 31, No 3-4, December 2009, pp. 59-66, University of Kragujevac - Faculty of Mechanical Engineering,

[7] Perić, S., Monitoring stanja kroz testove analize ulja, Vojnotehnički glasnik/Military Technical Courier, Vol. 58, No. 4, pp. 102-133, Beograd, 2010.

[8] Perić, S., Savremene metode analize ulja u tehničkim sistemima, Vojnotehnički glasnik/Military Technical Courier, Vol. 58, No. 1, pp. 83-112, Beograd, 2010. 
ZNAČAJ ANALIZE MAZIVA

OBLAST: mašinstvo, motori i motorna vozila

VRSTA ČLANKA: originalni naučni članak

Rezime

Praćenje radnih svojstava maziva u primeni ima višestruki značaj $i$ za korisnika i za proizvođača maziva. Za korisnika je to prvenstveno produžena i pravovremena zamena maziva, što čini troškove održavanja nižim. Za proizvođača maziva predstavlja stvaranje partnerskih odnosa sa potrošačem, ali i mogućnost prikupljanja informacija o ponašanju sopstvenih proizvoda kao osnove za dalje unapređenje i razvoj proizvoda.

Ako se tehnički sistemi žele održavati tako da imaju što manje zastoja $i$ troškova koji slede zbog otklanjanja zastoja i zbog toga što sistem ne obavlja svoju funkciju, onda tokom celog rada sistema treba pratiti podatke koji govore o stanju ispravnosti opreme. Posebno je teško dobiti podatke o stanju opreme kod onih delova koji su nepristupačni za posmatranje. U tim slučajevima analiza ulja omogućuje kontinuirano praćenje stanja opreme $i$ delovanje na vreme radi sprečavanja neželjenih dugotrajnih zastoja.

Uvod

Osnovna uloga maziva, odnosno podmazivanja, jeste da se smanji trenje i ujedno spreči habanje površina materijala koje se nalaze u međusobno relativnom kretanju. Ali, neophodno je da mazivo poseduje i ostala funkcionalna svojstva koja će osigurati njegovu efikasnu primenu. To je, pre svega, dobra oksidaciono-termička stabilnost, svojstvo zaštite od korozije, kompatibilnost s različitim materijalima, mala sklonost penjenju, sposobnost otpuštanja vazduha, dobra deterdžentno-disperzantna svojstva, dobra deemulzivnost $i$ sl.

Upotrebom maziva neizbežno dolazi do trajnog narušavanja njegovih radnih svojstava. Ove negativne promene najčešće su uzrokovane termičkim opterećenjem i/ili uticajem različitih vrsta zagađenja, kojim su maziva izložena prilikom eksploatacije. Termička opterećenja mogu nastati kao posledica velikih mehaničkih opterećenja ili dugotrajnog izlaganja povišenim temperaturama. Različite vrste zagađenja takođe predstavljaju čest uzrok degradacije maziva. Gasoviti produkti sagorevanja, vazduh, voda, glikol, gorivo, različiti procesni mediji, produkti habanja i ostali zagađivači mogu biti uzrok ozbiljnog narušavanja stanja maziva, ali i samog uređaja.

Stoga nužno treba pratiti promene radnih svojstava maziva, na osnovu kojih je moguće odrediti pravovremenu zamenu maziva, čime se produžava vek trajanja maziva i preventivno sprečavaju veći kvarovi ili oštećenja u sistemu.

Poznavanje analitičkih podataka maziva je podloga na osnovu koje se donose odluke u razvoju, proizvodnji i primeni maziva. Ispitivanja po kojima se određuju fizičko-hemijska svojstva maziva navedena su u specifikacijama, a realizuju se klasičnim metodama i raznim instrumen- 
talnim tehnikama. Prednost instrumentalnih tehnika je u maloj količini uzorka, brzoj analizi, ali zahteva posebno edukovano osoblje.

Različiti tehnički sistemi zahtevaju da se odgovarajuće mazivo primeni na pravom mestu, u pravo vreme i u pravoj količini. Racionalizacija potrošnje maziva predstavlja značajan zadatak, koji se uspešno može realizovati pravovremenom zamenom maziva. Time se obezbeđuje maksimalan period zamene uz istovremeno dovoljno kvalitetno podmazivanje. S obzirom na osnovnu ulogu maziva da redukuje negativne efekte triboloških procesa u pogledu trenja, habanja i rasta temperature u tribomehaničkim sistemima, svi vidovi održavanja uključuju podmazivanje kao veoma značajan deo ukupne procedure.

Mazivo je, kao kontaktni element tribomehaničkog sistema, nosilac informacija o stanju celog sistema s aspekta triboloških i drugih procesa starenja. Zbog toga analiza ulja na bazi pravilno definisanog programa predstavlja veoma efikasan metod monitoringa stanja tehničkih sistema koji obezbeđuje rane upozoravajuće znake potencijalnih problema, koji vode ka otkazu i zastoju tehničkih sistema.

Korišćenjem programa za analizu ulja u slučaju motornih ulja, osigurava se nekoliko prednosti: smanjenje neplaniranog vremena otkaza vozila, poboljšanje pouzdanosti vozila, što je od koristi prilikom organizovanja efikasnog plana održavanja, produženje radnog veka motora, optimiziranje intervala zamene ulja i smanjenje troškova održavanja vozila.

\section{Životni vek i analiza maziva}

Ako se tehnički sistemi žele održavati tako da imaju što manje zastoja $i$ troškova koji slede zbog otklanjanja zastoja i zbog toga što sistem ne obavlja svoju funkciju, onda tokom celog rada sistema treba pratiti podatke koji govore o stanju ispravnosti opreme. Posebno je teško dobiti podatke o stanju opreme kod onih delova koji su nepristupačni za posmatranje. U tim slučajevima analiza ulja omogućuje kontinuirano praćenje stanja opreme i delovanje na vreme radi sprečavanja neželjenih dugotrajnih zastoja.

Za praćenje promena radnih svojstava maziva na raspolaganju su brojne metode ispitivanja, bilo da se radi o konvencionalnim laboratorijskim tehnikama ili modernim instrumentalnim metodama. Određivanje stepena trošenja maziva može se realizovati modeliranjem ili eksperimentalno. Ocena istrošenosti najčešće nije jednoznačna i stoga se u praksi koriste različite metode u kombinaciji. U tu svrhu razvijaju se i nove metode koje će biti jednostavnije $i$ brže, jer je bitno dobiti podatke što pre na mestu primene $i$ to često na terenu. Zajednički nedostatak ovih metoda je što nisu standardizovane.

Mehanizam trošenja tribološkog sistema podmazivanja sastoji se od trošenja dodirnih površina i trošenja maziva. Ako dolazi do trošenja dodirnih površina, prisutne su čestice trošenja. Bez obzira na raspoloživost brojnih metoda za dijagnostikovanje fizičko-hemijskih promena maziva, za stvaranje prave slike o stanju maziva iz sistema korisnika bitan je preduslov mogućnost dobijanja reprezentativnog uzorka. Stoga je od posebne važnosti pravilan način uzimanja uzorka.

Degradacija svojstava maziva, odnosno stepen trošenja u toku primene ili ocena preostalog radnog veka, ispituje se različitim metodama. 
Određivanje stepena trošenja maziva može se realizovati modeliranjem ili eksperimentalno. Ocena istrošenosti najčešće nije jednoznačna $i$ stoga se $u$ praksi koriste različite metode u kombinaciji. $U$ tu svrhu razvijaju se i nove metode koje će biti jednostavnije i brže, jer je bitno dobiti podatke što pre na mestu primene i to često na terenu. Zajednički nedostatak ovih metoda je što nisu standardizovane.

Sledeći testovi su najčešće korišćeni testovi prilikom monitoringa stanja tehničkog sistema:

- spektrometrijska analiza,

- analitička ferografija,

- Rotrode filter spektroskopija (RFS),

- infracrvena analiza (FTIR),

- viskoznost,

- ukupni kiselinski broj (TAN),

- ukupni bazni broj (TBN),

- količina vode $i$ čestica.

Uticaj maziva na okolinu tokom primene

Korišćena ulja spadaju u kategoriju opasnog tehnološkog otpada, pa se njihovim odlaganjem sprečava moguće zagađenje okoline nastalo zbog njihovog nepravilnog odlaganja, odnosno mogućeg isticanja. Od ukupne svetske prerade nafte $1 \%$ se koristi za proizvodnju maziva.

Sve vrste maziva smatraju se zagađivačima okoline. Otpadna maziva svrstana su među opasne, toksične i kancerogene otpadne materijale, zagađivače zemljišta, vode $i$ atmosfere. Nosioci toksičnosti $i$ kancerogenosti su, pre svega, produkti oksidacione i termičke razgradnje maziva. Procesi oksidacije maziva odvijaju se konstantno, ne samo tokom eksploatacije, već i tokom skladištenja, pri čemu nastaju kiseli produkti, smole i asfalteni. Pod uticajem visokih temperatura, uz katalitičko delovanje vrućih metalnih površina klipova i cilindara (motorna ulja), nastaju štetni produkti koji sadrže policikličke aromate (PCA) različitih potencijala kancerogenosti.

$U$ nekim otpadnim uljima otkriveno je prisustvo polihloriranih bifenila (PCB), vrlo toksičnog i kancerogenog delovanja, koji razara imunološki sistem organizma. Osim toga, otpadna ulja sadrže azotne $i$ sumporne okside, kao produkte sagorevanja goriva sa kojima dolaze u dodir.

Nekontrolisano izlivanje otpadnih ulja opasno ugrožava okolinu narušavajući prirodnu ravnotežu. Koncentracija ulja u vodi od samo 1-2 mg po litru vodu čini nepitkom i štetnom za zdravlje. Još jedan vid opasnosti pojavljuje se pri spaljivanju otpadnih ulja I i II kategorije. Kako korišćena ulja sadrže aditive na osnovu jedinjenja (sumpora, azota, fosfora, teških metala) i koks i gasovi sagorevanja su vrlo štetni za ljudsko zdravlje.

Od profesionalnih bolesti pri radu s mazivima najčešći su dermatitis $i$ respiratorne bolesti. Dermatitis ili oboljenje kože javlja se u tri oblika, a to su: iritacija, hronična dermatoza i alergija. To je reakcija kože kao barijere organizma pri dodiru sa mazivom. Respiratorne bolesti (astma, bronhitis) rezultat su delovanja uljne magle ili aerosola koji se razvijaju u pogonima delovanjem povišenih temperatura, visokih brzina i sl. Između maziva (magla, aerosol) i ćelije respiratornog sistema dolazi do hemijske reakcije. 
Tribomehanički sistemi

Središnja komponenta tribomehaničkog sistema je mazivo čija je najznačajnija funkcija smanjenje trenja i trošenja koji se javljaju pri dodiru dve površine u relativnom kretanju. Kao podsistem tribomehanički sistemi svuda su integrisani u tehničke sisteme. Osim važnih primena u motorima sa unutrašnjim sagorevanjem, zupčastim prenosima $i$ hidrauličnim sistemima, postoji i veliki broj drugih primena. Zbog loše izvedbe tribomehaničkog sistema ili neodgovarajuće primene, ako nije prilagođen za dotični sistem, može doći do komercijalnih gubitaka koji se mere u bilionima evra godišnje. Zbog toga značaj tribosistema nije samo u tehničkom smislu nego i u ekonomskom i ekološkom. Koncept budućeg uspešnog razvoja pokušava da poveže ekonomiju i ekologiju u celovit neprotivrečan sistem.

Vozilo kao tehničko sredstvo predstavlja skup veoma složenih tribomehaničkih sistema sastavljenih od niza podsistema koji predstavljaju, takođe, složene tribomehaničke sisteme. Čine ih svi sklopovi koji učestvuju u prenosu snage, odnosno obrtnog momenta od motora, preko sklopova transmisije (menjača, razvodnika pogona, diferencijala i ostalih sklopova) do izvršnih organa vozila.

Ako se sklopovi motora sagledavaju sa aspekta tribomehaničkog sistema (npr. sklop klip-klipni prsten-cilindar; breg-podizač; ležaj-rukavac) definisanog tribološkim procesima, proizilazi da određivanje sadržaja produkata habanja, sadržaja kontaminata, stanja maziva i uslova podmazivanja ima znatan uticaj na realizaciju održavanja pomenutih sistema.

Posebno treba naglasiti značaj monitoringa ulja za podmazivanje sklopova tribomehaničkih sistema motora SUS, koji omogućava da se u ranoj fazi funkcionisanja sistema identifikuju eventualni uzročnici $i$ pojave koji vode ka oštećenju i otkazu. Prognoziranje, odnosno otkrivanje potencijalnih i/ili trenutnih oštećenja $i$ kvarova u sistemima, kao $i$ provera funkcionalnosti ulja i određivanje veka ulja glavni su faktori realizacije monitoringa ulja.

\section{Dijagnostika tribomehaničkih sklopova vozila}

Dijagnostika tribomehaničkog sistema može omogućiti proveru ispravnosti, radne sposobnosti i funkcionalnosti sistema, te ukazati na mesto, oblik i uzrok otkaza. Postaviti dijagnozu sistema moguće je otkrivanjem simptoma posredstvom određivanja vrednosti karakterističnih parametara i njihovim upoređivanjem sa dozvoljenim vrednostima. Dijagnostika tribomehaničkih sistema kod motornih vozila predstavlja deo ukupnog procesa upravljanja poslovima održavanja. Ona pruža mogućnost korisniku da predvidi oštećenja i/ili otkaze, te time spreči zastoj u radu i produži vek eksploatacije motornog vozila.

Suština dijagnostike zasnovana je na prognoziranju (prepoznavanju) oštećenja i/ili otkaza posredstvom karakterističnih dijagnostičkih parametara, što omogućava sprečavanje pojave zastoja, odnosno povećanje pouzdanosti, ekonomičnosti i veka eksploatacije sistema. Utvrdivanje osnovnih uzročnika otkaza i njihova eliminacija, potpunom kontrolom od- 
ređenih pojava, definiše proaktivno održavanje, kao novu metodu koja smanjuje troškove održavanja i produžava vek trajanja sredstva.

Kao deo zajedničke proaktivne strategije održavanja hidrauličnih i sistema za podmazivanje u poslednje vreme se uvodi takozvani on-line monitoring. To je kombinacija mernih postupaka, kod kojih se analizirani uzorak dovodi u merni instrument direktno iz sistema, a rezultati analiza se kontinuirano kontrolišu.

Savremeni trendovi dijagnostike poslednjih godina idu u pravcu afirmacije monitoringa ulja, što ima za posledicu porast interesovanja $i$ proizvođača i korisnika ulja. Razlozi, pre svega, leže u povećanju pouzdanosti, efektivnosti, ekonomičnosti i zaštite životne sredine.

Motorna ulja

Primarna uloga motornog ulja je podmazivanje pokretnih delova motora uz smanjenje trenja i habanja metalnih površina, te samim tim osiguravanje pravilnog rada motora i njegove dugovečnosti. Da bi se osigurao određeni kvalitet motornih ulja tokom proizvodnje $i$ da gotovi proizvodi zadovoljavaju proizvodne specifikacije potrebno je poznavati fizičko-hemijske karakteristike motornih ulja.

Određena fizičko-hemijska svojstva značajna za kvalitet motornih ulja postižu se dodatkom aditiva baznim uljima. Najčešće su u uporabi aditivi za:

- poboljšanje indeksa viskoznosti (impruveri),

- sniženje tačke stišnjavanja (depresanti),

- održavanje čistoće motora (detergenti i disperzanti),

- sprečavanje oksidacije (antioksidanti),

- sprečavanje korozije (inhibitori korozije).

Ispitivanje motornog ulja u toku eksploatacije

Ispitivane su fizičko-hemijske karakteristike ulja u skladu sa standardnim metodama koje su prikazane u tabeli 1 [3]. Analiza je vršena na svežem (novom) ulju i uljima koja su korišćena u sklopovima motora vozila. Ispitivanje korišćenih uzoraka vršena su u skladu sa zajednički definisanim kriterijumima kvaliteta za korišćena ulja.

Granice dozvoljenih odstupanja vrednosti pojedinih karakteristika ulja uslovljene su vrstom ulja, radnim uslovima i internim preporukama proizvođača maziva i korisnika. Limitirane vrednosti karakteristika ulja koje uslovljavaju izmenu uljnog punjenja iz motora navedene su u tabeli 2 [3]. One predstavljaju kriterijume za izmenu uljnog punjenja. Odstupanje samo jedne karakteristike uslovljava izmenu uljnog punjenja, bez obzira na to o kojoj karakteristici se radi.

Poreklo pojedinih elemenata u korišćenom motornom ulju (tabela 3) može da bude iz aditiva ( $\mathrm{Zn}$, Ca, Ba i Mg), od produkata habanja (Fe, $\mathrm{Pb}, \mathrm{Cu}, \mathrm{Cr}, \mathrm{Al}, \mathrm{Mn}, \mathrm{Ag}$ i Sn) i kontaminata koji potiču iz goriva, vazduha i tečnosti za hlađenje (Na, B, Si i Ca).

Ispitivanje je izvršeno na vozilu u kojem je ugrađen motor MercedesBenz EURO 2 OM 906 HLA. To je četvorotaktni motor sa šest cilindara postavljenih u liniji, turbo dizel, koji ispunjava EURO 2 norme vezane za 
emisiju izduvnih gasova. Tehnički podaci motora navedeni su u tabeli 4. U tabeli 5 prikazani su rezultati ispitivanja korišćenih uzoraka ulja.

U motoru je korišćeno motorno ulje FENIX SUPERIOR kvaliteta API SF-CD, gradacije SAE 15W-40. Za vreme ispitivanja autobus je saobraćao u uslovima gradske vožnje. Zadatak je bio provera intervala zamene motornog ulja na $20.000 \mathrm{~km}$. Analizom je ustanovljeno da su promene karakteristika motornog ulja očekivane i da se kreću u okviru dozvoljenih granica. Ispitivanje je realizovano periodičnim uzimanjem uzoraka ulja iz motora navedenog vozila. Osim svežeg ulja (,nulti” uzorak), uzeti su uzorci nakon $5.000 \mathrm{~km}, 10.000 \mathrm{~km}, 15.000$ i $20.000 \mathrm{~km}$. Nakon pređenih $20.000 \mathrm{~km}$ izvršena je zamena uljnog punjenja u motoru vozila.

\section{Zaključak}

Na osnovu dosadašnjeg razmatranja može se zaključiti:

- motorno ulje FENIX SUPERIOR, API SF-CD, gradacije SAE 15W-40, analizirano je u toku eksploatacije $i$ ostvaruje svoju osnovnu funkciju i zadovoljava predviđeni interval zamene od $20.000 \mathrm{~km}$ u motorima EURO 2 kategorije, što je ustanovljeno analizom karakterističnih fizičko-hemijskih osobina ulja i produkata habanja ( $F e$ ) tokom eksploatacije;

- pad viskoznosti evidentan je tokom prvih $5.000 \mathrm{~km}$, a nakon ovog perioda viskoznost ostaje približno konstantna do kraja intervala izmene uljnog punjenja. Maksimalni pad viskoznosti tokom eksploatacije ulja iz sva tri motora znatno je ispod dozvoljene granice od 20\%;

- nakon $20.000 \mathrm{~km}$ vrednost TBN-a je prekoračila dozvoljene granice za uzorke ulja iz motora;

- sadržaj nerastvorenih materija u ulju je zanemarljiv u odnosu na dozvoljene vrednosti, jer nema znatnije prisutnosti oksidacionih produkata i mehaničkih nečistoća, nerastvornih materija kao što su koks, kamenac, prašina, čađ, čestice habanja kontaktnih površina tribomehaničkih sistema motora SUS i drugih mehaničkih nečistoća;

- mali pad vrednosti tačke paljenja pokazuje da nije došlo do znatnijeg prodora goriva u sistem za podmazivanje;

- sadržaj gvožđa je ispod dozvoljene granice.

Potreba za što efikasnijim održavanjem i mogućnošću kontinuiranog korišćenja opreme razvila je čitav niz strategija i metoda održavanja opreme. Strategija održavanja po stanju, koja zahteva stalno praćenje i uvid u stanje opreme, uslovila je razvoj i primenu analize ulja. Ovakva analiza, osim stanja maziva, daje sliku stanja opreme tokom celog procesa korišćenja bez nepotrebnih gubitaka zbog zaustavljanja opreme.

Ključne reči: monitoring, održavanje, analiza ulja.

Datum prijema članka: 08. 12. 2011.

Datum dostavljanja ispravki rukopisa: 16. 01. 2012.

Datum konačnog prihvatanja članka za objavljivanje: 20. 01. 2012.

181 